\title{
An Overview of the Freshwater Crabs (Brachyura: Gecarcinucidae) of the Western Ghats, India
}

\author{
Sameer Kumar Pati ${ }^{1 *}$ and Rabi Narayan Pradhan ${ }^{2,3}$ \\ 1Zoological Survey of India, Western Regional Centre, Pune, India \\ 2Berhampur University, Odisha, India \\ 3Nuvapada Sri Balaji Mahavidyalaya, Ganjam, Odisha, India
}

Submission: July 07, 2020; Published: August 25, 2020

Corresponding author: Sameer Kumar Pati, Zoological Survey of India, Western Regional Centre, Vidyanagar, Akurdi, Pune, Maharashtra, India E-mail: sameer_pati@yahoo.co.in

\begin{abstract}
The Western Ghats has been well studied for freshwater crabs among the regions of the Indian subcontinent. Several studies on the Western Ghats crabs notwithstanding, their actual diversity is still incompletely known. The previous data on their diversity seems to be erroneous. The freshwater crabs of the Western Ghats are revisited to update the information on their diversity, distribution, endemism, and conservation, which include 888 locality records from 46 publications. The updated data comprises 62 crab species in 18 genera of the family Gecarcinucidae, including recognition of two new records from the Western Ghats: Oziotelphusa biloba and Oziotelphusa ravi. The Western Ghats crabs contribute nearly half the diversity of the Indian freshwater crabs and more than two-thirds the diversity of the Indian gecarcinucid crabs. Nearly two-thirds crab species of the Western Ghats have been reported during the last two decades. The Southern Western Ghats is relatively rich in crab diversity as compared to the Northern- and Central Western Ghats. Nearly one-third crab species of the Western Ghats are found above the average elevation and seven species above $2000 \mathrm{~m}$ altitude. Among the crab genera of the Western Ghats, Sahyadriana is the most species-rich followed by Ghatiana, Vanni, and Travancoriana. Although the Western Ghats crabs possess high-level endemism (67\% endemic genera and $82 \%$ endemic species), only two species have been considered as 'Vulnerable' and seven species as 'Least Concern' by the International Union for Conservation of Nature; the remaining species are either 'Data Deficient' or not assessed yet.
\end{abstract}

Kewords: Review; Crustacea; Decapoda; Diversity; Distribution; Endemism; Conservation; New Record

\section{Introduction}

The Western Ghats is a long stretch $(1600 \mathrm{~km})$ of mountain ranges running parallel to the western coast of the Indian peninsula in the states of Gujarat, Maharashtra, Goa, Karnataka, Tamil Nadu and Kerala (Figure 1). The peak of the Western Ghats is located at Anamudi of Kerala (2695 m above sea level). Some mountains are situated at lower elevations but fall within the limits of the Western Ghats. The Western Ghats is divided into three parts viz., 1) Northern Western Ghats (from Tapi valley to Goa); 2) Central Western Ghats (south of Goa-Nilgiris); and 3) Southern Western Ghats (south of Palghat gap) [1]. The Western Ghats along with Sri Lanka is one of the "hottest hotspots" and rich in faunal diversity [2,3]. The Western Ghats of India is home to many freshwater animals, including decapod crustaceans $[4,5]$.

Freshwater crabs are the decapod crustaceans, which play a significant ecological role in tropical freshwater ecosystems besides having economic importance [6,7]. Some species also contribute to small-scale fisheries and aquarium trade [6,7]. These animals recently revealed their high conservation priority [7]. They have also been considered phylogenetically important and biogeographically informative $[7,8]$.

Globally, 1564 species in five families of freshwater crabs are so far known [9]. Among these, 125 species in two families (Gecarcinucidae and Potamidae) are found in India [10-12]. The Western Ghats has gecarcinucid crabs only and previously reported to have 60 species [11]. They occupy a range of freshwater, semi-terrestrial, and terrestrial environments, including cryptic habitats like basalt rocks and phytotelmata $[10,14-16]$. The level of endemism is surprisingly high among the Western Ghats crabs [5]. This could be due to the isolated mountains that act as a geographical barrier in the form of 'sky islands' $[10,14,17]$. The freshwater crabs of the Western Ghats are revisited here with an aim to update the information on their diversity, distribution, 
endemism, and conservation. Records of the Western Ghats crabs from 888 localities (Figure 1) appeared in 46 publications [10,11,14-57] were analyzed for this review.

\section{Diversity}

The previous figure for the crabs of the Western Ghats seems to be erroneous, which shows the presence of 60 species $[10,11]$. Two species of Oziotelphusa (Oziotelphusa biloba and Oziotelphusa ravi) are found within the limits of the Western Ghats. While Oziotelphusa biloba was reported from few localities of Palakkad and Thrissur districts of Kerala [50,53], Oziotelphusa ravi has been recently described from a locality in Kanyakumari district of Tamil Nadu [52]. All these localities are clearly situated in the
Western Ghats. Although Oziotelphusa biloba and Oziotelphusa ravi have been reported on earlier occasions, both the species are recognized herein as the new records to the Western Ghats.

The updated data on the freshwater crabs of the Western Ghats revealed the presence of 62 species in 18 genera of the family Gecarcinucidae (Table 1). The Western Ghats crabs possess nearly half the number of Indian genera and species (18/35 genera and $62 / 125$ species) and more than two-thirds the number of the Indian gecarcinucid genera and species (18/24 genera and 62/90 species) [10-12]. The Southern Western Ghats has the highest diversity of freshwater crabs (27 species in 12 genera) followed by the Northern Western Ghats (27 species in 6 genera) and the Central Western Ghats (21 species in 8 genera) (Table 1).

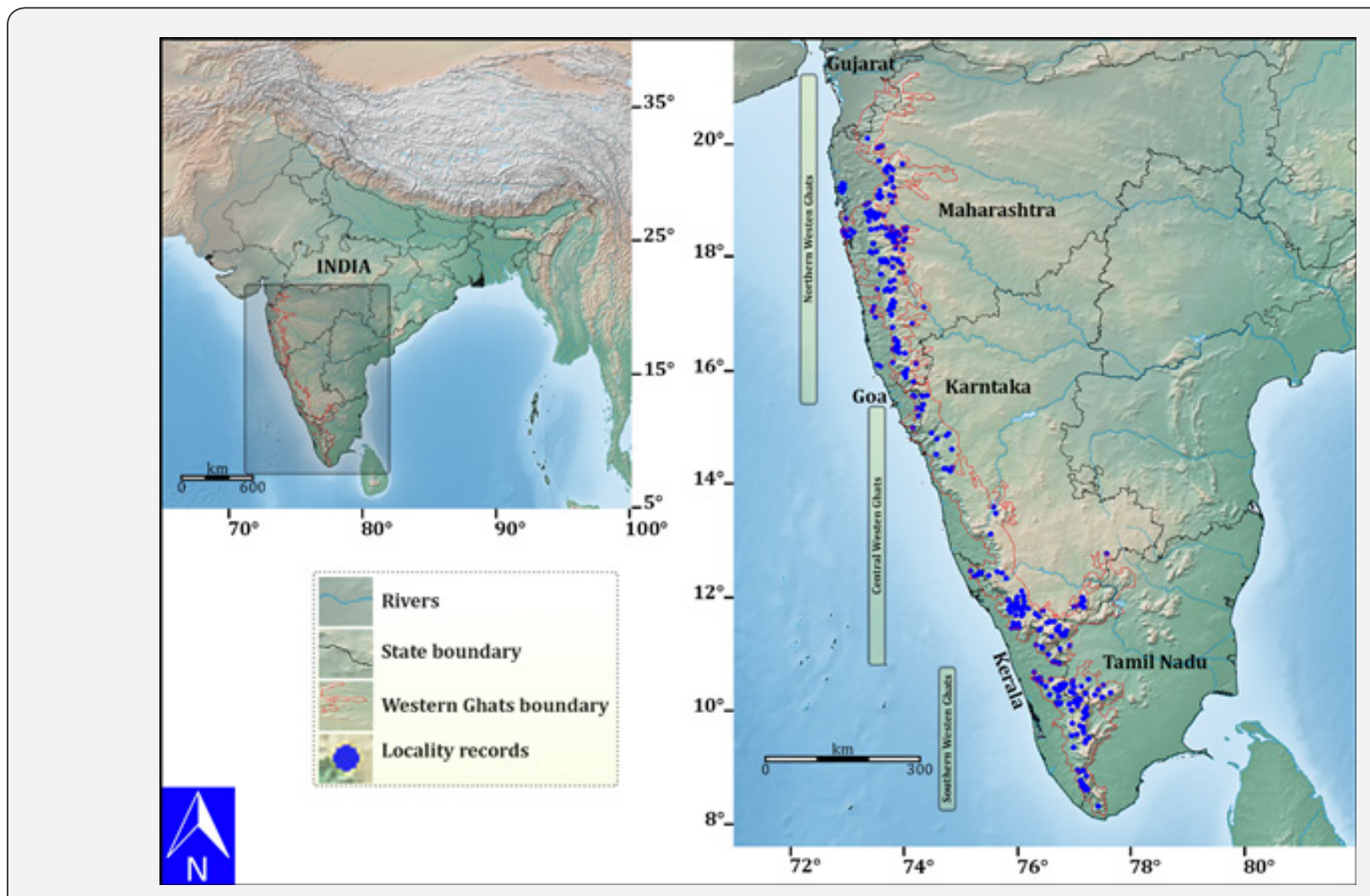

Figure 1: Map of the Western Ghats in India showing the locality records of the freshwater crabs.

The Northern Western Ghats seems to be relatively well studied for the freshwater crabs as far as the genus-species proportion and locality records are concerned (Figure 1). The Central Western Ghats is poorly explored, which is evident from the smaller number of locality records (Figure 1). Sahyadriana is the most species-rich genus (10 species) in the Western Ghats followed by Ghatiana (8 species), Vanni (7 species), and Travancoriana ( 6 species). The remaining genera possess less than five species, with Inglethelphusa, Kani and Lamella are monotypic.
All the known species of each genus are found in the Western Ghats except for Cylindrotelphusa and Oziotelphusa (Figure 2).

The first-ever species recorded from the Western Ghats is currently known as Barytelphusa cunicularis, which was originally described as Thelphusa cunicularis by J O Westwood in the work of W H Sykes during 1836 [18]. Thereafter, many crab species were described or reported from the Western Ghats [10,11,14-17,1957], especially during the last two decades that contribute nearly two-thirds of the currently known species (Figure 3). 


\section{Oceanography \& Fisheries Open access Journal}

Table 1: List of freshwater crabs of the Western Ghats and their distribution.

\begin{tabular}{|c|c|c|c|c|c|c|}
\hline \multirow[b]{2}{*}{ Species } & \multicolumn{5}{|c|}{ Distribution } & \multirow{2}{*}{$\begin{array}{l}\text { IUCN Red List } \\
\text { Status }\end{array}$} \\
\hline & NWG & CWG & SWG & $\begin{array}{l}\text { Altitudinal range } \\
\text { (m ASL) }\end{array}$ & Endemic to WG & \\
\hline $\begin{array}{l}\text { Genus Arcithelphusa Pati \& Sudha Devi, } \\
2015\end{array}$ & - & + & - & $709-864$ & Yes & \\
\hline $\begin{array}{l}\text { 1. Arcithelphusa cochleariformis Pati \& Sudha } \\
\text { Devi, } 2015\end{array}$ & - & + & - & $709-864$ & Yes & $\mathrm{NE}$ \\
\hline $\begin{array}{l}\text { 2. Arcithelphusa tumpikkai Pati, Sujila \& Sudha } \\
\text { Devi, } 2019\end{array}$ & - & + & - & $729-860$ & Yes & $\mathrm{NE}$ \\
\hline Genus Baratha Bahir \& Yeo, 2007 & - & - & + & $1160-1290$ & Yes & \\
\hline 3. Baratha peena Bahir \& Yeo, 2007 & - & - & + & $1160-1260$ & Yes & DD \\
\hline 4. Baratha pushta Bahir \& Yeo, 2007 & - & - & + & 1290 & Yes & DD \\
\hline Genus Barytelphusa Alcock, 1909 & + & + & + & $3-2231$ & No & \\
\hline $\begin{array}{l}\text { 5. Barytelphusa cunicularis (Westwood in } \\
\text { Sykes, 1836) }\end{array}$ & + & + & + & $3-2231$ & No & LC \\
\hline $\begin{array}{l}\text { 6. Barytelphusa guerini (H. Milne-Edwards, } \\
\text { 1853) }\end{array}$ & + & - & - & $4-1277$ & No & LC \\
\hline 7. Barytelphusa mccanni (Chopra \& Das, 1935) & + & + & - & $74-1386$ & No & $\mathrm{NE}$ \\
\hline Genus Cylindrotelphusa Alcock, 1909 & - & + & + & $46-980$ & No & \\
\hline $\begin{array}{l}\text { 8. Cylindrotelphusa breviphallus Pati, Rajesh, } \\
\text { Raj, Sheeja, Kumar \& Sureshan, } 2017\end{array}$ & - & - & + & $920-945$ & Yes & $\mathrm{NE}$ \\
\hline 9. Cylindrotelphusa steniops (Alcock, 1909) & - & + & + & $46-980$ & No & LC \\
\hline $\begin{array}{c}\text { Genus Gecarcinucus H. Milne Edwards, } \\
1844\end{array}$ & + & - & - & $82-991$ & No & \\
\hline 10. Gecarcinucus edwardsi Alcock, 1909 & + & - & - & $302-991$ & No & DD \\
\hline $\begin{array}{l}\text { 11. Gecarcinucus jacquemontii H. Milne Ed- } \\
\text { wards, } 1844\end{array}$ & + & - & - & $82-933$ & No & LC \\
\hline Genus Ghatiana Pati \& Sharma, 2014 & + & + & - & $54-1104$ & No & \\
\hline $\begin{array}{l}\text { 12. Ghatiana atropurpurea Pati, Thackeray \& } \\
\text { Khaire, } 2016\end{array}$ & + & + & - & $54-736$ & No & $\mathrm{NE}$ \\
\hline 13. Ghatiana aurantiaca Pati \& Sharma, 2014 & + & - & - & $215-277$ & Yes & $\mathrm{NE}$ \\
\hline $\begin{array}{l}\text { 14. Ghatiana basalticola (Klaus, Fernandez \& } \\
\text { Yeo, 2014) }\end{array}$ & - & + & - & $778-852$ & Yes & $\mathrm{NE}$ \\
\hline 15. Ghatiana botti Pati \& Thackeray, 2018 & + & - & - & $66-145$ & Yes & $\mathrm{NE}$ \\
\hline 16. Ghatiana hyacintha Pati \& Sharma, 2014 & + & - & - & $883-997$ & Yes & $\mathrm{NE}$ \\
\hline 17. Ghatiana pulchra Pati \& Thackeray, 2018 & + & - & - & 1104 & Yes & $\mathrm{NE}$ \\
\hline $\begin{array}{l}\text { 18. Ghatiana rathbunae Pati \& Thackeray, } \\
2018\end{array}$ & + & - & - & 977 & Yes & $\mathrm{NE}$ \\
\hline $\begin{array}{l}\text { 19. Ghatiana splendida Pati, Thackeray \& } \\
\text { Khaire, } 2016\end{array}$ & + & - & - & $839-853$ & Yes & $\mathrm{NE}$ \\
\hline Genus Gubernatoriana Bott, 1970 & + & - & - & $306-1386$ & Yes & \\
\hline $\begin{array}{l}\text { 20. Gubernatoriana gubernatoris (Alcock, } \\
\text { 1909) }\end{array}$ & + & - & - & $1055-1386$ & Yes & DD \\
\hline $\begin{array}{l}\text { 21. Gubernatoriana longipes Pati \& Thackeray, } \\
\qquad 2018\end{array}$ & + & - & - & $687-688$ & Yes & $\mathrm{NE}$ \\
\hline $\begin{array}{l}\text { 22. Gubernatoriana marleshwarensis Pati \& } \\
\text { Thackeray, } 2018\end{array}$ & + & - & - & 306 & Yes & NE \\
\hline $\begin{array}{l}\text { 23. Gubernatoriana wallacei Pati \& Thackeray, } \\
\qquad 2018\end{array}$ & + & - & - & $1051-1075$ & Yes & $\mathrm{NE}$ \\
\hline Genus Inglethelphusa Bott, 1970 & + & - & - & $800-1272$ & Yes & \\
\hline 24. Inglethelphusa fronto (Alcock, 1909) & + & - & - & $800-1272$ & Yes & DD \\
\hline
\end{tabular}




\begin{tabular}{|c|c|c|c|c|c|c|}
\hline Genus Kani Raj \& Ng, 2017 & - & - & + & 372 & Yes & \\
\hline 25. Kani maranjandu Raj \& Ng, 2017 & - & - & + & 372 & Yes & $\mathrm{NE}$ \\
\hline $\begin{array}{l}\text { Genus Karkata Pati, Rajesh, Raj, Sheeja, } \\
\text { Kumar \& Sureshan, } 2017\end{array}$ & - & - & + & $43-793$ & Yes & \\
\hline $\begin{array}{l}\text { 26. Karkata ghanarakta Pati, Rajesh, Raj, Shee- } \\
\text { ja, Kumar \& Sureshan, } 2017\end{array}$ & - & - & + & $43-555$ & Yes & $\mathrm{NE}$ \\
\hline $\begin{array}{l}\text { 27. Karkata kusumbha Pati, Rajesh, Raj, Shee- } \\
\text { ja, Kumar \& Sureshan, } 2017\end{array}$ & - & - & + & 793 & Yes & $\mathrm{NE}$ \\
\hline Genus Lamella Bahir \& Yeo, 2007 & - & - & + & $43-889$ & No & \\
\hline 28. Lamella lamellifrons (Alcock, 1909) & - & - & + & $43-889$ & No & LC \\
\hline Genus Oziotelphusa Müller, 1887 & - & + & + & $46-839$ & No & \\
\hline 29. Oziotelphusa biloba Bahir \& Yeo, 2005 & - & + & + & $89-145$ & No & $\mathrm{VU}$ \\
\hline 30. Oziotelphusa Raj, Kumar \& Ng, 2017 & - & - & + & 46 & Yes & NE \\
\hline $\begin{array}{l}\text { 31. Oziotelphusa wagrakarowensis (Rathbun, } \\
\text { 1904) }\end{array}$ & - & + & - & $583-839$ & No & $\mathrm{VU}$ \\
\hline Genus Pilarta Bahir \& Yeo, 2007 & - & - & + & $40-1784$ & Yes & \\
\hline 32. Pilarta anuka Bahir \& Yeo, 2007 & - & - & + & $920-975$ & Yes & DD \\
\hline $\begin{array}{l}\text { 33. Pilarta aroma Pati, Rajesh, Raj, Sheeja, } \\
\text { Kumar \& Sureshan, } 2017\end{array}$ & - & - & + & 1784 & Yes & $\mathrm{NE}$ \\
\hline $\begin{array}{l}\text { 34. Pilarta punctatissima Pati, Rajesh, Raj, } \\
\text { Sheeja, Kumar \& Sureshan, } 2017\end{array}$ & - & - & + & $40-46$ & Yes & $\mathrm{NE}$ \\
\hline Genus Sahyadriana Pati \& Thackeray, 2018 & + & - & - & $12-1319$ & Yes & \\
\hline $\begin{array}{l}\text { 35. Sahyadriana alcocki (Pati in Pati et al., } \\
\text { 2016) }\end{array}$ & + & - & - & 1082 & Yes & $\mathrm{NE}$ \\
\hline $\begin{array}{l}\text { 36. Sahyadriana billyarjani Pati \& Thackeray, } \\
\qquad 2018\end{array}$ & + & - & - & $499-600$ & Yes & $\mathrm{NE}$ \\
\hline $\begin{array}{l}\text { 37. Sahyadriana pachyphallus Pati \& Thacker- } \\
\text { ay, } 2018\end{array}$ & + & - & - & 493 & Yes & $\mathrm{NE}$ \\
\hline 38. Sahyadriana pilosipes (Alcock, 1909) & + & - & - & $1096-1272$ & Yes & DD \\
\hline $\begin{array}{l}\text { 39. Sahyadriana sahyadriensis Pati \& Thacker- } \\
\text { ay, } 2018\end{array}$ & + & - & - & $12-808$ & Yes & $\mathrm{NE}$ \\
\hline $\begin{array}{l}\text { 40. Sahyadriana tenuiphallus Pati \& Thacker- } \\
\text { ay, } 2018\end{array}$ & + & - & - & 596 & Yes & $\mathrm{NE}$ \\
\hline $\begin{array}{l}\text { 41. Sahyadriana thackerayi (Pati in Pati et al., } \\
\text { 2016) }\end{array}$ & + & - & - & 499 & Yes & $\mathrm{NE}$ \\
\hline $\begin{array}{l}\text { 42. Sahyadriana triangulus (Pati \& Sharma, } \\
\text { 2014) }\end{array}$ & + & - & - & $1055-1207$ & Yes & $\mathrm{NE}$ \\
\hline $\begin{array}{l}\text { 43. Sahyadriana waghi (Pati in Pati, Thackeray } \\
\text { \& Khaire, 2016) }\end{array}$ & + & - & - & $588-1319$ & Yes & $\mathrm{NE}$ \\
\hline $\begin{array}{l}\text { 44. Sahyadriana woodmasoni Pati \& Thacker- } \\
\text { ay, } 2018\end{array}$ & + & - & - & 1006 & Yes & $\mathrm{NE}$ \\
\hline Genus Snaha Bahir \& Yeo, 2007 & - & - & + & $327-2350$ & Yes & \\
\hline 45. Snaha aruna Bahir \& Yeo, 2007 & - & - & + & 1800 & Yes & DD \\
\hline 46. Snaha escheri (Roux, 1931) & - & - & + & $327-2350$ & Yes & DD \\
\hline Genus Travancoriana Bott, 1969 & - & + & + & $127-2472$ & No & \\
\hline 47. Travancoriana charu Bahir \& Yeo, 2007 & - & - & + & $339-920$ & Yes & DD \\
\hline 48. Travancoriana convexa (Roux, 1931) & - & + & + & $141-1300$ & Yes & LC \\
\hline $\begin{array}{l}\text { 49. Travancoriana granulata Pati \& Sharma, } \\
\qquad 2013\end{array}$ & - & - & + & $1708-2472$ & Yes & $\mathrm{NE}$ \\
\hline 50. Travancoriana kuleera Bahir \& Yeo, 2007 & - & + & - & $728-800$ & Yes & DD \\
\hline 51. Travancoriana pollicaris (Alcock, 1909) & - & + & + & $338-1244$ & Yes & DD \\
\hline
\end{tabular}




\section{Oceanography \& Fisheries Open access Journal}

\begin{tabular}{|c|c|c|c|c|c|c|}
\hline 52. Travancoriana schirnerae Bott, 1969 & - & + & + & $127-2231$ & No & LC \\
\hline Genus Vanni Bahir \& Yeo, 2007 & - & + & + & $24-2200$ & Yes & \\
\hline 53. Vanni ashini Bahir \& Yeo, 2007 & - & + & + & $118-975$ & Yes & $\mathrm{DD}$ \\
\hline 54. Vanni deepta Bahir \& Yeo, 2007 & - & - & + & 685 & Yes & $\mathrm{DD}$ \\
\hline 55. Vanni giri Bahir \& Yeo, 2007 & - & + & + & $661-1570$ & Yes & $\mathrm{DD}$ \\
\hline 56. Vanni malabarica (Henderson, 1912) & - & + & + & $24-628$ & Yes & $\mathrm{DD}$ \\
\hline 57. Vanni nilgiriensis (Roux, 1931) & - & + & - & $816-2200$ & Yes & $\mathrm{DD}$ \\
\hline 58. Vanni pusilla (Roux, 1931) & - & + & - & 2100 & Yes & $\mathrm{DD}$ \\
\hline 59. Vanni travancorica (Henderson, 1913) & - & + & + & $100-1094$ & Yes & $\mathrm{DD}$ \\
\hline Genus Vanni Bahir \& Yeo, 2007 & - & + & + & $728-2231$ & Yes & \\
\hline 60. Vela carli (Roux, 1931) & - & + & - & $728-1116$ & Yes & $\mathrm{DD}$ \\
\hline 61. Vela pulvinata (Alcock, 1909) & - & + & - & $901-2231$ & Yes & $\mathrm{DD}$ \\
\hline 62. Vela virupa Bahir \& Yeo, 2007 & - & - & + & $1050-1140$ & Yes & $\mathrm{DD}$ \\
\hline
\end{tabular}

NWG: Northern Western Ghats; CWG: Central Western Ghats; SWG: Southern Western Ghats; ASL: above sea level; WG: Western Ghats; IUCN: International Union for Conservation of Nature; '+' present; '-' absent; NE: Not evaluated; DD: Data Deficient; LC: Least Concern; VU: vulnerable

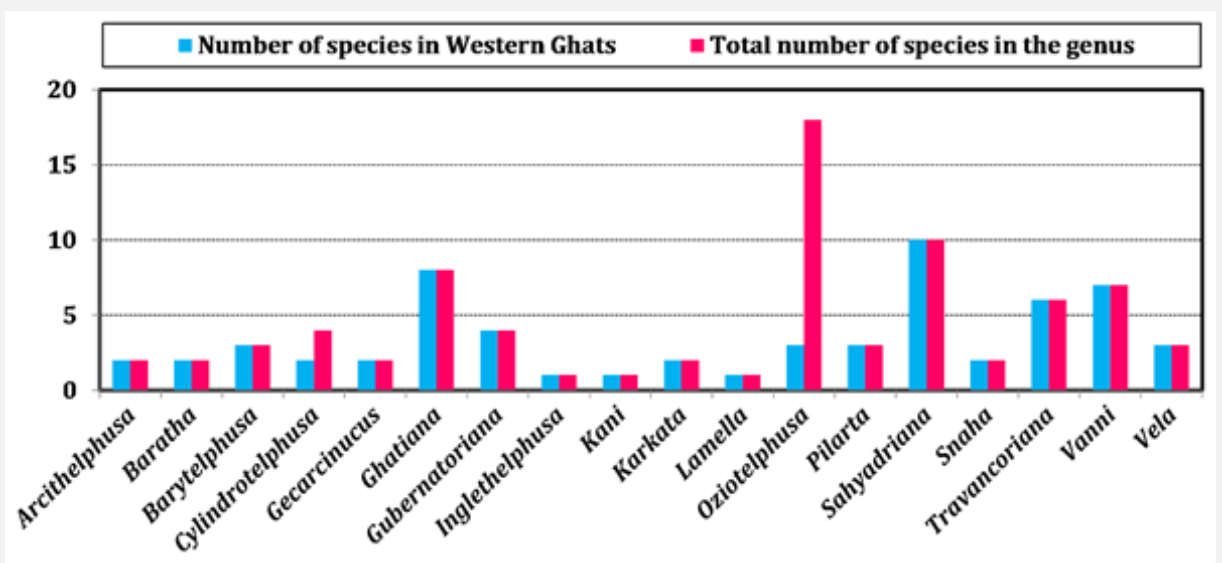

Figure 2: Freshwater crab genera of the Western Ghats, each showing number of species in the Western Ghats and total number of species.

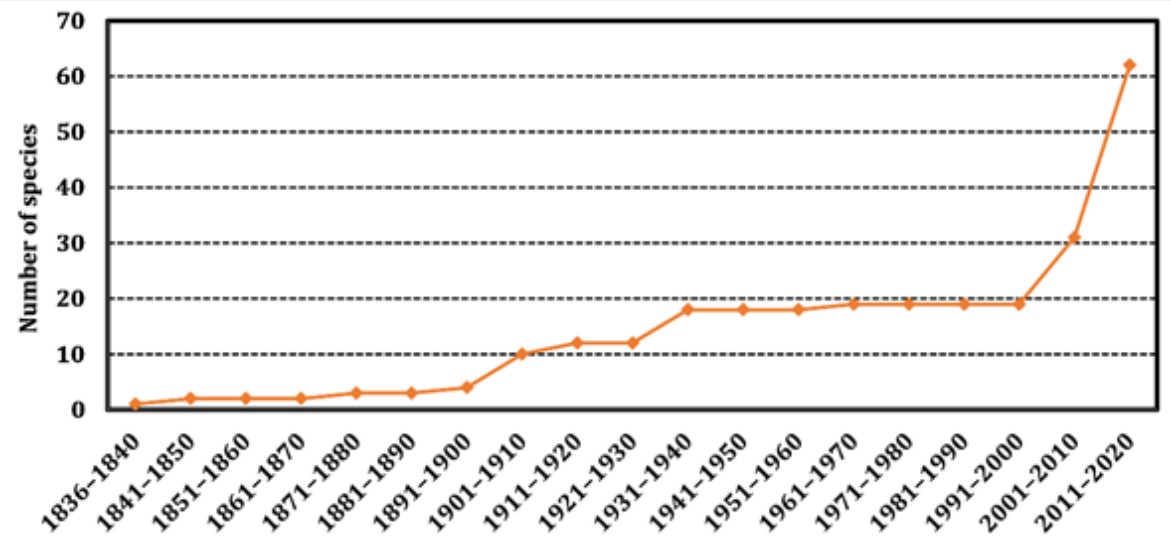

Figure 3: Species-accumulation curve for the freshwater crabs of the Western Ghats during 1836-2019. 

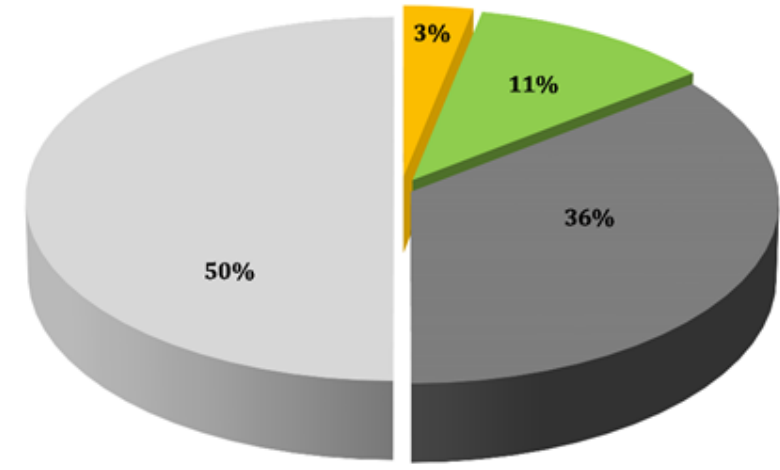

= Vulnerable (2 species)

= Least Concern (7 species)

- Data Deficient (22 species)

Not evaluated (31 species)

Figure 4: Composition of the conservation status of the Western Ghats crabs according to the IUCN Red List.

\section{Distribution}

The freshwater crabs of the Western Ghats are distributed all over the region from low-lying areas to high mountain peaks (3$2472 \mathrm{~m}$ above sea level) (Table 1). As many as 10 genera (56\%) and 21 species (34\%) are found above the average elevation (1200 m) of the Western Ghats (Table 1). Seven species, viz. Barytelphusa cunicularis, Snaha escheri, Travancoriana granulata, Travancoriana schirnerae, Vanni nilgiriensis, Vanni pusilla, and Vela pulvinata, dwell above $2000 \mathrm{~m}$ elevation (Table 1). While most of these species are also found at relatively lower altitudes, Travancoriana granulata and Vanni pusilla are always restricted to highly elevated areas (1708-2472 m) [17, 31,35,36,39,53].

Among the freshwater crabs of the Western Ghats, 27 species in 6 genera are found in the Northern Western Ghats; 21 species in 8 genera in the Central Western Ghats; and 27 species in 12 genera in the Southern Western Ghats (Table 1). Barytelphusa cunicularis is the only species that widely occurs in the Western Ghats. On the other hand, most of the genera and species show a distinct pattern of distribution within the Western Ghats. Some of these genera (Gecarcinucus and Lamella) and species (Barytelphusa guerini and Oziotelphusa wagrakarowensis), however, are also found beyond the limit of the Western Ghats. Among the genera, Gecarcinucus, Gubernatoriana, Inglethelphusa, and Sahyadriana are distributed in the Northern Western Ghats only; Arcithelphusa in the Central Western Ghats only; and Baratha, Kani, Karkata, Lamella, Pilarta, and Snaha in the Southern Western Ghats only (Table 1). Among the species, Barytelphusa guerini and all the species of Ghatiana except for Ghatiana basalticola are distributed in the Northern Western Ghats only; Ghatiana basalticola, Oziotelphusa wagrakarowensis, Travancoriana kuleera, Vanni nilgiriensis, Vanni pusilla, Vela carli, and Vela pulvinata in the Central Western Ghats only; and Cylindrotelphusa breviphallus, Oziotelphusa ravi, Travancoriana charu, Travancoriana granulata, Vanni deepta, and Vela virupa in the Southern Western Ghats only (Table 1).

\section{Endemism}

Currently, nearly $63 \%$ genera $(22 / 35$ genera) and $86 \%$ species $(107 / 125$ species $)$ of the freshwater crabs are endemic to India. Similarly, the Western Ghats crabs also show a high level of endemism, with $67 \%$ endemic genera (12/18 genera) and $82 \%$ endemic species (51/62 species) (Table 1). Nearly half of the endemic species of the Western Ghats (25/51 species) are highly restricted in distribution and so far, known only from their type locality [10,14-17,31,39,49,52,55].

Among the endemic crabs of the Western Ghats, Gubernatoriana (4 species), Inglethelphusa (1 species), and Sahyadriana (10 species) are restricted only to the Northern Western Ghats; Arcithelphusa (2 species) only to the Central Western Ghats; and Baratha (2 species), Kani (1 species), Karkata (2 species), Pilarta (3 species), and Snaha (2 species) only to the Southern Western Ghats (Table 1). In addition to the species of these endemic genera, as many as 18 endemic species of the Western Ghats are restricted only either to the Northern Western Ghats (e.g., Ghatiana aurantiaca, Ghatiana botti, Ghatiana hyacintha, Ghatiana pulchra, Ghatiana rathbunae, and Ghatiana splendida) or the Central Western Ghats (e.g., Ghatiana basalticola, Travancoriana kuleera, Vanni nilgiriensis, Vanni pusilla, Vela carli, and Vela pulvinata) or the Southern Western Ghats (e.g., Cylindrotelphusa breviphallus, Oziotelphusa ravi, Travancoriana charu, Travancoriana granulata, Vanni deepta, and Vela virupa) (Table 1).

\section{Conservation}

Conservation of freshwater crabs is essential because the proportion of freshwater crabs threatened with extinction is almost equal to that of reef-building corals and exceeds that of Odonata, freshwater fishes, reptiles, birds, and mammals [7]. The conservation of the Western Ghats crabs is nevertheless a challenge because the majority of the species (53/62 species, $86 \%$ ) are either 'Data Deficient' (22 species, 36\%) or not being evaluated for their conservation status (31 species, $50 \%$ ) by the 
International Union for Conservation of Nature (IUCN) (Figure 4) (Table 1) [58]. While seven species (11\%) were given the status of 'Least Concern', only two species (Oziotelphusa biloba and Oziotelphusa wagrakarowensis) had been categorized as 'Vulnerable' by the IUCN (Figure 4) (Table 1) [58].

\section{Conclusion}

Most of the freshwater crabs of the Western Ghats are known either from the type locality or from a few localities only. More surveys and explorations, especially from the Central- and Southern Western Ghats, are, therefore, needed to know their actual distributional range. With the rapid discovery rate, it is currently difficult to estimate their actual diversity. Many more taxa are yet to be described from this region, especially from the cryptic habitats. That is why a complete monograph on the Western Ghats crabs is a few decades away. Some genera (Arcithelphusa, Barytelphusa, Cylindrotelphusa, Travancoriana, and Vanni) need an urgent taxonomic revision. Moreover, a complete phylogeny of the freshwater crabs of the Western Ghats is likely to reveal many changes in their systematic position. Conservation of freshwater crabs of the Western Ghats is a matter of concern because most of the species lack important information like distributional range and population size, which are very crucial in the assessment of the conservation status. Most of the species in the Western Ghats, however, are endemic and can only tolerate a small range of environmental conditions. Those species are very likely to face severe threats. In these situations, the present review will aid as updated and baseline information in advancing our understanding of the freshwater crabs of the Western Ghats.

\section{Acknowledgement}

The first author is grateful to Dr Kailash Chandra, Director (Zoological Survey of India, Kolkata) for research facilities and constant encouragement. The first author gratefully acknowledges Dr Peter K.L. Ng and Dr Darren C.J. Yeo (National University of Singapore) for their continuous guidance on the subject. We would like to thank the following for their contributions on material, data, and time: Dr Santanu Mitra (Crustacea Division, Zoological Survey of India, Kolkata); Dr P.M. Sureshan (Western Ghat Regional Centre, Zoological Survey of India, Kozhikode); Dr A. Biju Kumar, Smrithy Raj and L. Rajesh (Department of Aquatic Biology and Fisheries, University of Kerala, Thiruvananthapuram, Kerala, India); Dr A.R. Sudha Devi and P.S. Sujila (Department of Zoology and Research Centre, Mary Matha Arts and Science College, Mananthavady, Kerala, India); S. Sheeja (Department of Zoology, Holy Cross College, Nagercoil, Tamil Nadu, India); T. Thackeray (a wildlife conservationist from Mumbai).

\section{References}

1. Pascal JP (1988) Wet Evergreen Forests of the Western Ghats of India. Institut Français de Pondichéry, Pondicherry, Pp. 1-156.

2. Myers N, Mittermeier RA, Mittermeier CG, da Fonseca GAB, Kent J
(2000) Biodiversity hotspots for conservation priorities. Nature 403: 853-858.

3. Gunawardene NR, Dulip Daniels AE, Gunatilleke IAUN, Gunatilleke CVS, Karunakaran PV, et al. (2007) A brief overview of the Western GhatsSri Lanka biodiversity hotspot. Current Science 93(11): 1567-1572.

4. Molur S, Smith KG, Daniel BA, Darwall WRT (2011) The status and distribution of freshwater biodiversity in the Western Ghats, India. IUCN, UK and Gland, Switzerland, and Zoo Outreach Organisation, Coimbatore, India, Pp. 1-116.

5. Raghavan R, Dahanukar N, Philip S, Iyer P, Kumar B, et al. (2015) The conservation status of decapod crustaceans in the Western Ghats of India: an exceptional region of freshwater biodiversity. Aquatic Conservation: Marine and Freshwater Ecosystems 25(2): 259-275.

6. Yeo DCJ, Ng PKL, Cumberlidge N, Magalhaes C, Daniels SR, et al. (2008) Global diversity of crabs (Crustacea: Decapoda: Brachyura) in freshwater. Hydrobiologia 595(1): 275-286.

7. Cumberlidge N, Ng PKL, Yeo DCJ, Magalhaes C, Campos MR, et al. (2009) Freshwater crabs and the biodiversity crisis: Importance, threats, status, and conservation challenges. Biological Conservation 142(8): 1665-1673.

8. Klaus S, Schubart CD, Streit B, Pfenninger M (2010) When Indian crabs were not yet Asian - biogeographic evidence for Eocene proximity of India and Southeast Asia. BMC Evolutionary Biology 10: 287.

9. WoRMS Editorial Board (2020) World Register of Marine Species.

10. Pati SK, Thackeray T (2018) The freshwater crab genera Ghatiana Pati \& Sharma, Gubernatoriana Bott, and Inglethelphusa Bott (Crustacea: Decapoda: Brachyura: Gecarcinucidae) revisited, with descriptions of a new genus and eleven new species. Zootaxa 4440(1): 1-73.

11. Pati SK, Sujila PS, Sudha Devi AR (2019) Description of a new species of freshwater crab of the genus Arcithelphusa Pati \& Sudha Devi, 2015 (Decapoda: Brachyura: Gecarcinucidae) from the Western Ghats, Kerala, India. Zootaxa 4674(2): 203-214.

12. Mitra S (2019) A new species of Himalayapotamon Pretzmann, 1966 (Decapoda: Brachyura: Potamidae: Potaminae) from Western Himalaya, India. Journal of Environment \& Sociobiology 16(2): 121131.

13. Pati SK, Vargila F (2019) A new species of the freshwater crab genus Oziotelphusa Müller, 1887 from Tamil Nadu, India (Crustacea, Decapoda, Brachyura, Gecarcinucidae). Spixiana 42(2): 203-216.

14. Klaus S, Fernandez K, Yeo DCJ (2014) Phylogeny of the freshwater crabs of the Western Ghats (Brachyura, Gecarcinucidae). Zoologica Scripta 43(6): 651-660.

15. Pati SK, Thackeray T, Khaire A (2016) Five new species of freshwater crabs of the genera Ghatiana Pati \& Sharma, 2014, and Gubernatoriana Bott, 1970 (Crustacea, Decapoda, Brachyura: Gecarcinucidae Rathbun, 1904) from the Western Ghats, India. Zootaxa 4083(4): 569-586.

16. Kumar AB, Raj S, Ng PKL (2017) Description of a new genus and new species of a fully arboreal crab (Decapoda: Brachyura: Gecarcinucidae) from the Western Ghats, India, with notes on the ecology of arboreal crabs. Journal of Crustacean Biology 37(2): 157-167.

17. Pati SK, Sharma RM (2013) A new species of freshwater crab, Travancoriana granulata n. sp. (Brachyura: Gecarcinucidae) from the southern Western Ghats of India. Zoosystematics and Evolution 89(2): 275-281.

18. Sykes WH (1836) Some account of the land crabs of the Dukhun by Lieut. Col. W.H. Sykes with a description of the species by J.O. Westwood. The Transactions of the Entomological Society of London 1(3): 181-184. 
19. Milne Edwards H (1844) Crustacés. In: Jacquemont V (Ed), Voyage dans l'Inde, par Victor Jacquemont, pendant les années 1828 à 1832 Description des Collections. Tome Quatrième. Firmin Didot Frères, Paris, France, P. 1-9.

20. Wood-Mason J (1871) Contribution to Indian Carcinology-On Indian and Malayan Telphusidae, Part-I. Journal of the Asiatic Society of Bengal 40(2): 189-200.

21. Wood-Mason J (1871) Contribution to Indian Carcinology-On Indian and Malayan Telphusidae, Part-I. Journal of the Asiatic Society of Bengal 40(3): 201-207.

22. Henderson JR (1893) A Contribution to Indian Carcinology. The Transaction of the Linnean Society of London 5(10): 325-458.

23. Ortmann AE (1897) Carcinologische Studien. Zoologische Jahrbücher Abteilung für Systematik, Geographie und Biologie der Thiere 10(3): 258-372.

24. De Man JG (1898) Viaggio di Leonardo Fea in Birmanica e regioni vicine LXXXI-Note sur quelques espèces des genres Parathelphusa H.M.E. et Potamon Sav. recueillies par M. Leonardo Fea pendant son voyage en Birmanie. Annali del Museo civico di Storia naturale di Genova 19(39): 384-440.

25. Rathbun MJ (1905) Les crabes d'eau douce (Potamonidae). Nouvelles Archives du Muséum d'Histoire Naturelle, Paris (4) 7: 159-321.

26. Rathbun MJ (1906) Les crabes d'eau douce (Potamonidae). Nouvelles Archives du Muséum d'Histoire Naturelle, Paris (4) 8: 33-122.

27. Alcock A (1909) Diagnoses of new species and varieties of freshwater crabs. Nos. 4. Records of the Indian Museum 3(4): 375-381.

28. Alcock A (1910) Catalogue of the Indian decapod Crustacea in the collection of the Indian Museum. Part I. Brachyura. Fasciculus II. The Indian fresh-water crabs-Potamonidae. Indian Museum, Calcutta, India, Pp. 1-135.

29. Henderson JR (1912) Description of a new species of freshwater crab from Southern India. Records of the Indian Museum 7(2): 111-112.

30. Henderson JR (1913) A new variety of freshwater crab from Travancore. Records of the Indian Museum 9(2): 47-49.

31. Roux J (1931) Crustacés Décapodes d'eau douce de l'Inde méridionale. Revue Suisse de Zoologie 38(2): 31-62.

32. McCann C (1937) Notes on the common land crab Paratelphusa (Barytelphusa) guerini (M.-Eds.) of Salsette Island. Journal of the Bombay Natural History Society 39(3): 531-542.

33. Ramakrishna G (1951) Notes on some Indian Potamonid crabs (Crustacea: Decapoda). Records of the Indian Museum 48(2): 89-92.

34. Bott R (1969) Flußkrabben aus Asien und ihre Klassifikation (Crustacea, Decapoda). Senckenbergiana Biologica 50(5/6): 359-366.

35. Bott R (1970) Die Süßwasserkrabben von Europa, Asien, Australien und ihre Stammesgeschichte. Eine Revision der Potamoidea und Parathelphusoidea (Crustacea, Decapoda). Abhandlungen der Senckenbergischen Naturforschenden Gesellschaft 526: 1-338.

36. Bott R (1970) Betrachtungen über die Entwicklungsgeschichte und Verbreitung der Süsswasser-Krabben nach der Sammlung des Naturhistorischen Museums in Genf/Schweiz. Revue Suisse de Zoologie 77(2): 327-344.

37. Srivastava OP (2005) Freshwater crabs (potamonids) in the collection of the Southern Regional Station, Zoological Survey of India, Chennai. Records of the Zoological Survey of India 104(1-2): 115-122.

38. Srivastava OP, Krishnan S (2006) Crustacea: Decapoda: Gecarcinucidae (Crabs). In: The Director (Ed), Fauna of Biligiri Rangaswamy Temple
Wildlife Sanctuary (Karnataka), Conservation Area Series 27. Zoological Survey of India, Kolkata, India, Pp. 17-20.

39. Bahir MM, Yeo DCJ (2007) The gecarcinucid freshwater crabs of southern India (Crustacea: Decapoda: Brachyura). Raffles Bulletin of Zoology, Supplement 16: 309-354.

40. Srivastava OP (2007) Crustacea: Brachyura: Crabs. In: The Director (Ed), Fauna of Bannerghatta National Park, Conservation Area Series 33. Zoological Survey of India, Kolkata, India, Pp. 33-37.

41. Ghatak SS, Ghosh SK (2008) Crustacea: Decapoda: Palaemonidae: Gecarcinucidae. In: The Director (Ed.), Fauna of Goa, State Fauna Series 16. Zoological Survey of India, Kolkata, India, Pp. 165-172.

42. Pati SK, Sharma RM (2011) New record of a freshwater crab Vanni travancorica from Uttar Kannada district of Karnataka. Bionotes 13(4): 152.

43. Pati SK, Sharma RM (2012) Freshwater crabs of some protected areas and wetlands, Maharashtra. Bionotes 14(4): 126-127.

44. Thigale D (2012) Study of freshwater crabs and prawns (Arthropoda: Crustacea: Decapoda) of Krishna River at Sangli and Wai, Maharashtra. M.Sc. Dissertation, University of Pune, Pune, India.

45. Srivastava OP (2013) Crustacea: Decapoda: Gecarcinucidae (Freshwater and Land Crabs). In: The Director (Ed.) Fauna of Karnataka, State Fauna Series 21. Zoological Survey of India, Kolkata, India, Pp. 73-78.

46. Pati SK, Sharma RM (2014) Freshwater crabs (Crustacea: Decapoda: Brachyura: Gecarcinucidae) in the collection of the Western Regional Centre, Pune. Records of the Zoological Survey of India, Occasional Paper 363: 1-44.

47. Pati SK, Sharma RM (2014) Freshwater crabs (Crustacea: Decapoda: Brachyura: Gecarcinucidae). In: The Director (Ed.), Fauna of Chandoli National Park. Conservation Area Series 51. Zoological Survey of India, Kolkata, India, Pp. 59-64.

48. Pati SK, Sharma RM (2014) Freshwater crabs (Crustacea: Decapoda: Brachyura: Gecarcinucidae). In: The Director (Ed.), Fauna of Radhanagari Wildlife Sanctuary, Conservation Area Series 52. Zoological Survey of India, Kolkata, India, Pp. 115-120.

49. Pati SK, Sharma RM (2014) Description of Ghatiana, a new genus of freshwater crab, with two new species and a new species of Gubernatoriana (Crustacea: Decapoda: Brachyura: Gecarcinucidae) from the Western Ghat Mountains, India. Journal of Natural History 48(21-22): 1279-1298.

50. Pati SK, Sharma RM, Sureshan PM (2014) Freshwater crabs (Crustacea: Decapoda: Brachyura: Gecarcinucidae) in the collection of Western Ghat Regional Centre, Zoological Survey of India, Kozhikode. Records of the Zoological Survey of India 114(4): 651-668.

51. Pati SK, Sudha Devi AR (2015) Description of a new genus and new species of freshwater crab (Brachyura: Gecarcinucidae) from the Western Ghats, Kerala, India. Zoological Studies 54: 35.

52. Raj S, Kumar AB, Ng PKL (2017) A new species of freshwater crab of the genus Oziotelphusa Müller, 1887 (Crustacea: Decapoda: Brachyura: Gecarcinucidae) from Tamil Nadu, southern India. Zootaxa 4363(2): 225-236.

53. Rajesh L, Raj S, Pati SK, Kumar AB (2017) The freshwater crabs (Decapoda: Brachyura) of Kerala, India. Journal of Aquatic Biology \& Fisheries 5: 132-153.

54.Pati SK, Sharma RM (2017) Freshwater crabs (Brachyura: Gecarcinucidae). In: The Director (Ed), Fauna of Phansad Wildlife Sanctuary, Maharashtra, Conservation Area Series 59. Zoological Survey of India, Kolkata, India, Pp. 9-14. 
55. Pati SK, Rajesh L, Raj S, Sheeja VU, Kumar AB, et al. (2017) Karkata, a new genus of gecarcinucid freshwater crab with two new species, and four new species of Pilarta Bahir and Yeo, 2007 and Cylindrotelphusa Alcock, 1909 (Decapoda: Brachyura) from Kerala, India. Journal of Natural History 51(23-24): 1295-1330.

56. Pati SK, Sujila PS, Sudha Devi AR (2019) New records of two species of freshwater crabs (Decapoda: Gecarcinucidae) from Kerala, India, with notes on their distribution. Nauplius 27: e2019006.
57. Pati SK, Sharma RM, Sureshan PM (2019) Freshwater crabs (Decapoda: Brachyura: Gecarcinucidae). In: The Director (Ed), Fauna of Malabar Wildlife Sanctuary, Kozhikode, Kerala, Conservation Area Series 62 Zoological Survey of India, Kolkata, India, Pp. 11-15.

58. IUCN (2020) The IUCN Red List of Threatened Species.
Your next submission with Juniper Publishers will reach you the below assets

- Quality Editorial service

- Swift Peer Review

- Reprints availability

- E-prints Service

- Manuscript Podcast for convenient understanding

- Global attainment for your research

- Manuscript accessibility in different formats ( Pdf, E-pub, Full Text, Audio)

- Unceasing customer service

Track the below URL for one-step submission https://juniperpublishers.com/online-submission.php 